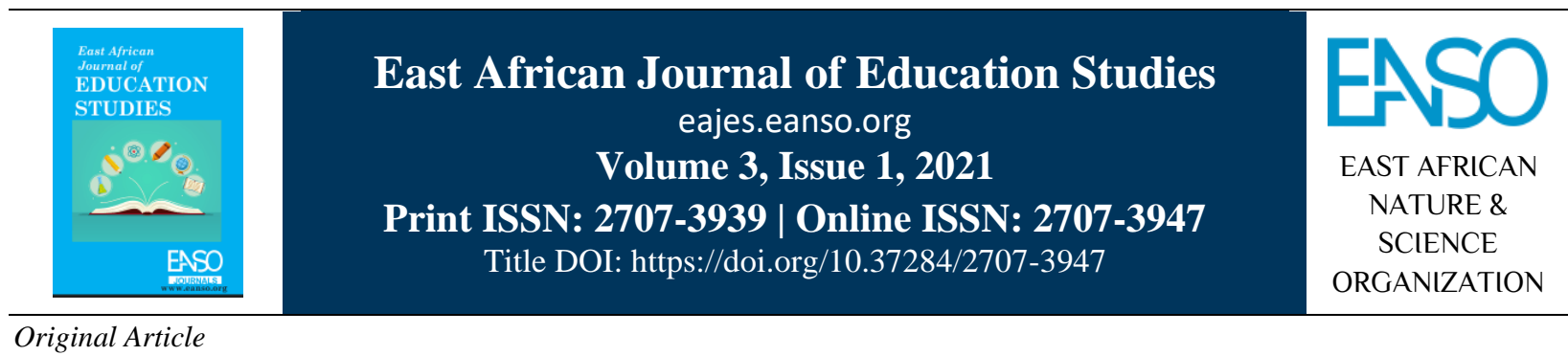

\title{
Non-Examined Secondary School Curriculum and Quality Teacher Education: Case of University of Nairobi Students on Teaching Practice in Meru
}

\author{
Prof. Jane Ciumwari Gatumu, $P h D^{* 1} \&$ Dr. John Chandi Rugendo, $P h D^{l}$ \\ ${ }^{1 *}$ School of Education, University of Nairobi, P. O. Box 30197 - 00100, Nairobi, Kenya. \\ *ORCID: https://orcid.org/0000-0002-1762-9361; Correspondence Email: jgatumu@ uonbi.ac.ke.
}

Article DOI: https://doi.org/10.37284/eajes.3.1.338

Date Published: ABSTRACT

07 June 2021 Student teachers in teaching practice find themselves in a scenario whereby they are examined based only on their pedagogical competencies. This paper focuses

Keywords: on the student teachers' quality in relation to the non-examined curriculum

Non-Examined

Curriculum,

Examined

Curriculum,

Quality,

Teaching Practice,

Teacher Education. component, where the goal of the curriculum is to develop the life skills of students. A phenomenological approach and social constructivist framework are relied upon. The study's sample size consisted of 47 University of Nairobi students in the Meru teaching practice zone. The students were observed and interviewed to find out the nature of their involvement in the non-examined curriculum. The data collection was guided by activities they participated in, reasons for their participation, how the school administration supported their involvement and how this contributed to their self-fulfilment as teachers of quality. The research findings indicate that student teachers appreciate the quality and relevance of their teacher preparation courses and the central importance of their relationships with learners that are entrusted to them. It emerged that their teaching of non-examined curriculum displayed their expertise which raised their morale when they were teaching the examined curriculum. Precisely, their teaching of non-examined curriculum created a forum for student teachers to feature in their local communities, neighbourhoods and at the county level, which made them feel that they have something to offer to the wider society. Furthermore, the study highlights the student teachers' concerns with developing identities as 'teachers' and the ample opportunities provided during teaching practice for them to try out what was learned during teacher training preparation. Observing these 47 students depicted their high levels of passion, confidence, creativity and intrinsic motivation, features of quality preparation for teaching

106| This work is licensed under a Creative Commons Attribution 4.0 International License. 
practice. The study recommends the essence of investing in quality teacher training preparation programmes.

\section{APA CITATION}

Gatumu, J. C., \& Rugendo, J. C. (2021). Non-Examined Secondary School Curriculum and Quality Teacher Education: Case of University of Nairobi Students on Teaching Practice in Meru. East African Journal of Education Studies, 3(1), 106-115. https://doi.org/10.37284/eajes.3.1.338.

\section{CHICAGO CITATION}

Gatumu, Jane Ciumwari, and John Chandi Rugendo. 2021. "Non-Examined Secondary School Curriculum and Quality Teacher Education: Case of University of Nairobi Students on Teaching Practice in Meru". East African Journal of Education Studies 3 (1), 106-115. https://doi.org/10.37284/eajes.3.1. 338.

\section{HARVARD CITATION}

Gatumu, J. C. and Rugendo, J. C. (2021) "Non-Examined Secondary School Curriculum and Quality Teacher Education: Case of University of Nairobi Students on Teaching Practice in Meru", East African Journal of Education Studies, 3(1), pp. 106-115. doi: 10.37284/eajes.3.1. 338 .

\section{IEEE CITATION}

J. C. Gatumu, and J. C. Rugendo, "Non-Examined Secondary School Curriculum and Quality Teacher Education: Case of University of Nairobi Students on Teaching Practice in Meru”, EAJES, vol. 3, no. 1, pp 106-115, Apr. 2021.

\section{MLA CITATION}

Gatumu, Jane Ciumwari, and John Chandi Rugendo. "Non-Examined Secondary School Curriculum and Quality Teacher Education: Case of University of Nairobi Students on Teaching Practice in Meru". East African Journal of Education Studies, Vol. 3, no. 1, Apr. 2021, pp. 106-115, doi:10.37284/eajes.3.1.338.

\section{INTRODUCTION}

The general purpose of teaching practice is to have student teachers be full participant observers in the link between the theory component and the practical situation of a classroom. According to Claessen, Ndichu and Groenewegen (1995), teaching practice is a complex activity that demands personal decision-making by the student-teacher in terms of what to do and how to do it. Of all the objectives of the teaching practice, the key one is to provide a student-teacher with space to practice and be supervised (Erlich \& Shaughnessy, 2014; Digolo, 2002) in the formal curriculum to be examined both internally and externally. To Kasomo (2012), assessment of the learning outcomes is limited to the formal academic curriculum and the rest of the student teacher's time during teaching practice is taken for granted.

To ascertain quality, teaching practice is organised along two sections: preparatory and placement in schools to allow expertise supervision accompanied by feedback (Digolo \& Okanga, 1991). During the preparatory stage, the student teachers are empowered in knowledge, skills, attitudes and abilities acquisition in areas of subject specialisation and pedagogy. For instance, at the preparatory phase, a student-teacher undertakes simulated teaching/mock teaching/micro-teaching activities under the supervision of a subject specialist (Igaga, 1972). In micro-teaching, a student-teacher practically undertakes small-scale teaching lasting 5 to 15 minutes to about 5 to 15 peers, instead of the normal 40 students, in a simulated class. A specific teaching skill like the use of questions is simulated under the process of set induction, stimulus variation and closure to allow mastery of it. In the second section, students are placed in schools relevant to their programme across Kenya so that they get ample time to 'try out' pedagogical knowledge, skills, values and attitudes of their subject specialisation. In a one-to-one tutoring and mentoring experience, the student-teacher demonstrates his/her ability to tie theory and practice, crucial to be a teacher. Each encounter between the student teacher and the subject specialist is accompanied by verbal and written feedback. Thus, during the placement, the studentteacher is practically taught, and his/her performance is examined. This makes the placement experience be the culminating moment of the teacher education programme (Msangya, Mkoma \& Yihuan, 2016). It is only when these two sections are completed that a student-teacher can authoritatively claim to be a classroom practitioner and a professional in teaching. 
The student-teacher during teaching practice goes beyond the academic programme in that he/she participates in the non-examinable component of students' life through extracurricular activities (Shiundu \& Omulando, 1998). This nonexaminable curriculum is implemented under extracurricular activities. The extracurricular activities being the nongraded part of the curriculum takes place after the formal curriculum hours. It may be referred to as the social-emotional curriculum, which may not have a professionally qualified teacher to managing it. Student teachers in teaching practice find themselves assigned the responsibility to get involved in this curriculum either by choice or by the school administration allocating to them that they must participate in, though the university does not have guidelines on how to assess them. The concern of this paper is about how this nonexaminable programme (extracurricular activities) relates to how well the student performs in the academic programme. It is an area a student teacher on teaching practice invests heavily in terms of time, energy and emotional status though knowing that it does not add value to the final teaching practice grade.

The Kenya government recognises the importance of extracurricular activities. According to State House News Release, former President Kibaki's speech in 2010 at the National Music and Drama Festivals acknowledged the important role extracurricular activities have in serving as a catalyst for the development of national, social, political and economic development. To the former president, extracurricular activities inspire, educate and enrich the human experience and provide meaningful entertainment and constructive use of leisure time.

In Kenya, emphasis is placed on competition in both extracurricular activities and academic curriculum. The trends at national extracurricular activities competitions and national examinations in secondary schools have indicated a positive relationship between outstanding academic performance and exemplary extracurricular activities performance (Omoke, 2009; Eshiwani, 1993). Schools have developed systems that ensure that their students participate at all levels of recognition and competition: school, zonal, subcounty, county and national.
A study by Omoke (2009) examined the role of cocurricular activities in a student's social and academic development in Suneka, Kenya. The study showed that the activities enhanced students' discipline, tolerance, cooperation, responsibility, choice-making and accepting defeat honourably. According to Acquah and Pertey (2014), extracurricular activities enable students to apply theoretical knowledge in practical situations like what happens in life, hence allowing wholistic growth development of an individual. Acquah \& Partey (2014) carried out an investigation on correlating students' co-curricular activities to their performance in Economics in Ghanaian secondary schools. Using the logit analysis model, they found a positive relationship between the two. The current study was done with student teachers on teaching practice to establish how they performed in their teaching practice as they implemented extracurricular activities. This research was guided by the following four objectives: to examine what activities teachers on teaching practice participate in; to establish reasons for their involvement in the stated extracurricular activities; to assess the support they receive from the school administration in relation to their involvement, and to determine the teachers on teaching practice level of selfesteem arising from their involvement in extracurricular activities.

\section{RESEARCH METHODOLOGY}

The investigation employed a descriptive survey research design with the focus on what is happening to the teaching practice students in their involvement in extracurricular activities. It employed qualitative approaches to let research participants be accessed individually to describe their experiences in extracurricular activities. Using a phenomenological approach and a social constructivist framework, 47 students in the Meru teaching practice zone were observed and interviewed to investigate the nature of their involvement in a non-examined curriculum. This qualitative framework has the advantage in that though teaching practice is complex, it was possible to have student teachers participate and make the involvement in extracurricular activities clear. Their current experiences formed the basis of penetrating into that which they are participating in. 
The 47 student teachers were selected randomly from a population of 83 student teachers on teaching practice in the Meru Teaching practice zone in 2016-2017. This gave us a set of participants from both females $(n=21)$ and males $(n=26)$ from 31 schools.

Each student was observed at least once during the teaching practice and a summary of the observation was recorded in the field notes. At the end of the teaching practice, each one of them was interviewed for about twenty minutes and a summary was made immediately in accordance with recommendations given by Anderson (1990); Bogdan and Biklen (1992).

The research employed a triangulation of interviewing, observing and a documentary analysis of the teaching practice results as ways to understand the phenomena under investigation. In addition, the same questions were posed to the 47 interviewees to countercheck reliability, a necessary condition of validity.

The collected data was accessed and coded according to the objectives. The focus was given to what the student emphasised as he/she responded to the oral questions. The qualitative component of their responses was maintained. What was obtained from the interview and observations were tied to individual student's final grades in the teaching practice? The frequencies and percentages were recorded. And the mean per each extracurricular activity category was calculated. The range for each category of activity was kept as a way of retaining some specific raw scores for individual research participants' details. Data were analysed following the thematic approach, in which emerging ideas were clustered into themes in the creation of an overall threshold image of the qualitative observation. This was done by reading the transcripts as well as the field notes which included the observation remarks and the summaries from the documentary analysis to establish the sense and meaning of what the participants said. The emerging themes were treated as findings to the specific research objectives.

The research was also conducted in alignment with ethical principles. Specifically, the anonymity of the participants and the confidentiality of the information that the participants provided were maintained. Anonymity entailed not revealing the identity of the research participants (McLeod, 1999). Confidentiality implied that though we knew our research participants and their information, we would not provide the connection to the public unless the information (Fraenkel, Wallen \& Hyun, 1993). To develop a relationship that was based on trust and confidence, we endeavoured to have a rapport with each of the 47 research participants that we interviewed.

\section{FINDINGS AND DISCUSSION}

The study's findings are organised along with the three objectives.

\section{Student Teachers' Extracurricular Activities and their Performance}

The first objective of this study was to establish the kind of extracurricular activities student teachers participated in. Table 1 shows categories of these extracurricular activities that student teachers were involved in and their final teaching practice.

Table 1: Categories of student teachers' extracurricular activities and performance

\begin{tabular}{lllll}
\hline Type of co-curricular activity & f & $\mathbf{\%}$ & Mean score & Range \\
\hline Sports & 14 & 30 & 72 & $66-78$ \\
Music & 5 & 11 & 68 & $60-79$ \\
Drama & 3 & 6 & 69 & $60-73$ \\
Religious & 8 & 17 & 70 & $67-77$ \\
Guidance and counselling/ Mentoring & 6 & 13 & 71 & $53-80$ \\
Academic oriented activities & 8 & 17 & 69 & $65-80$ \\
Administration & 3 & 6 & 74 & $72-79$ \\
Total & $\mathbf{4 7}$ & $\mathbf{1 0 0}$ & \\
\hline
\end{tabular}

$109 \mid$ This work is licensed under a Creative Commons Attribution 4.0 International License. 
Table 1 displays that each of the 47 student teachers had an extracurricular activity. From the table, it is evident that though they participated in extracurricular activities, they performed well in their teaching practice (53-80\%). This may imply that the 47 teachers had been properly mentored to undertake their teaching practice and that the exercise had been properly planned and organised as suggested by Heeralal (2014) and Mungure (2016), respectively. This must be understood in the context of their quality time management, an aspect of being able to set priorities and by observing personal discipline core concerns of theory before teaching practice (Coulangeon, 2018; Macan et al., 1990).

The highest mean score of $74 \%(n=3)$ was from those who took part in administrative activities, a task that expects the student teacher to take charge of all students when not undergoing the academic programme. Being on duty means that the studentteacher is relied upon to take charge and control of school non-academic programme to run (Okumbe, 1998). The high scores could be due to intrinsic motivation sanctioned by highly recognised administrative positions of trust by the regular school administrators. For instance, two students in this category of extracurricular activity were involved in interacting with students on a Sunday night to ease a tense situation that would have led to a strike. Another student in this category narrated an incident when he was on duty and the students were rowdy and complained about uncooked food and it was dramatic the way he calmed the students and together with the deputy headteacher had the situation under control. These are success stories for the student teachers on the journey towards their teaching profession. Such results indicate that student teachers' involvement in administrative issues makes them grow into responsible adults who accept the consequences of their own decisions and actions, an aspect that demonstrates maturity. This is supported by Digolo and Okanga (1991) who also call upon student teachers on teaching practice to portray the best of their control when dealing with students' tendency towards indiscipline.

The music and drama extracurricular activities groups were among those with the lowest mean scores of $68 \%$ and $69 \%$ for their teaching practice, respectively. These extracurricular activities require a lot of input from the student-teacher in terms of initiating learners' creativity, confidence and responsibility. During the supervision, one student had been away for a drama festival and when she came back to school, she had to be assessed in her teaching with an extremely sketchy lesson plan to guide her classroom interaction, making her not perform well in that lesson. She was advised to balance her time well so that the academic curriculum does not suffer, and she responded positively. In fact, she was the student with the highest mark of $73 \%$ in the drama extracurricular activity category. To the outside world, she was a great success and this form of recognition motivated her to continue. To this extent, success becomes marked by how well they managed their time as suggested by Heeralal (2014) who argued that balancing teaching and extracurricular activity is a skill a teaching practice student should display because of the complexity of the activity.

The academic-oriented co-curricular activities are directed by student teachers who utilised their academic expertise to experience the essence of their subject and they had a mean score of $69 \%$. The activities in this category included debating and poetry, Kiswahili, Mathematics, Science and Geography clubs. The student teachers in these activities were passionate about the subject areas they were teaching. For instance, one student in this group who scored $80 \%$ argued that he was in Geography club activities because it was his area of expertise. What seemed central in these activities was the focus the student teachers laid on successful innovations of the expertise and lifestyles of key personalities in these areas. Students in these activities ended sharpening their academic skills, values and knowledge academically. Tabot (2015) and Broh (2002) observed and reported that most students who engage in extracurricular activities related to academic curriculum gain positively in their performance.

In the guidance and counselling extracurricular activity category, we had a student who scored 53\%, the lowest mark in the whole group. This was a student who throughout the teaching practice in and out of school because of ill health. Her sickly condition did not hinder her from getting involved in counselling and mentoring students. Her focus on counselling was that learners should make use of 
the given time and not give up even when all is not well. In this same group, there was a student who featured mentoring students by having each student make a journal and diary for personal experiences and time management. At the end of the week, he would have students share their journal experiences and this seemed to encourage group members in their academic endeavour. They would raise issues of concern which would be addressed by the group and every time. They would come with a plan of action in the following meeting. This student with journal and diary keeping activity scored $80 \%$ in her final teaching practice. This is because mentoring and counselling are about being models to the students (Heeralal, 2014). To model, one needs to exhibit the best for others to emulate because they admire it. The mentee students end up craving to be like their mentors. Many student teachers in this group were passionate about what they were doing and had an outward outlook which was to give the best to their students.

The religious extracurricular activities involved two religious organisations: The Young Catholic Students Association and Christian Union, both known for conducting lively morning assemblies and welfare projects to the schools' neighbourhood had a mean score of $70 \%$. The student teachers in this group worked on their personal developments by enhancing responsibility, altruism, independence, aspects of moral development. It was in this group the student teachers would have an opportunity to invite outside guests who would display more modelling behaviour for students to observe. This enabled the school to link up with the local communities, sources of enthusiasts to help learners gain specific skills relevant to their future lives.

The category of extracurricular activity with the largest number of students was sports, $30 \%(n=14)$ and a mean score of $72 \%$. It included athletics, football, volleyball, basketball and netball. The existence of these activities was obvious as the facilities like soccer fields, netball courts, netball were noticeable as one got into the school compound. Gathua (1990) argues that these facilities attracted the involvement of the students in various activities. The existence of these activities in all the 31 schools is in the context of Kenya Vision 2030, with a focus on the promotion of healthy and active lifestyles for students as the destiny of a nation depends on the health and strength of its citizens. In fact, one of the national goals of education in Kenya is to promote positive attitudes towards good health (Republic of Kenya, 2017). Through sporting activities schools provide many opportunities for students to engage in vigorous physical activity and are thus better placed amongst societal institutions to motivate them to live active lifestyles (Jenkinson \& Benson, 2010). The 14 student teachers in this category of extracurricular activities were able to set a climate for their students to engage in sporting activities. This finding corroborates the findings of Marsh and Kleitman (2002), who observed that more time is spent on sports than other structured extracurricular activities by students. Schools tend to give sports activities much prominence and it was observed that those who engaged in these activities are given special treatment in terms of their feeding. Also, they were exempted from activities like compound and dormitory cleaning. The building of team spirit really thrilled the students as they were able to excel under student teachers' control. More so, the global physical activity guidelines by WHO recommends that children and youth 5-17 years of age should accumulate an average of at least 60 minutes of daily moderate-to-vigorous physical exercise to improve and maintain fitness and body composition profile (WHO, 2010).

\section{Student Teachers' Reasons for the Involvement and their Performance}

Each of the 47 students was expected to give a reason as to why he/she got involved in extracurricular activities. Table 2 shows student teachers' reasons for the involvement and their final teaching practice academic performance.

Table 2: Reasons for extracurricular activities

\begin{tabular}{lllll}
\hline Reason & f & \% & Mean score & Range \\
\hline Interest and ability in the activity & 13 & 28 & 72 & $60-79$ \\
Pay back to the school/community & 05 & 11 & 72 & $60-80$
\end{tabular}

111| This work is licensed under a Creative Commons Attribution 4.0 International License. 


\begin{tabular}{lllll}
\hline Reason & f & $\mathbf{\%}$ & Mean score & Range \\
\hline Model/mentor & 07 & 15 & 70 & $53-80$ \\
Keep them busy/control of discipline & 08 & 17 & 72 & $66-79$ \\
Enhance social-emotional skills & 11 & 23 & 71 & $67-74$ \\
Different from classwork/Variety & 3 & 6 & 72 & $66-80$ \\
Total & $\mathbf{4 7}$ & $\mathbf{1 0 0}$ & & \\
\hline
\end{tabular}

Table 2 shows high mean scores for all categories of reasons for involvement in extracurricular activities. The proportion of those who stated that their choice was because of their interest and ability in the activity was $28 \%(\mathrm{n}=13)$ with a teaching practice mean score of $72 \%$. This group of student teachers were concerned with what they were good at and therefore wanted to display it and be judged by their students and colleagues as they learn it. Their participation in extracurricular activities became an opportunity for many of them to display an intelligence they had for their students to practise (Gardener, 1999). In support of this, Acquah and Pertey (2014) argue that learners have different aptitudes and are given opportunities for development before specialising in a specific field of interest.

Enhancing students' social-emotional skills is the number two reason for involvement, with $23 \%$ ( $\mathrm{n}=$ 11) of the student teachers having a mean score of $71 \%$. Social-emotional skills have been regarded to be a key variable in students' academic curriculum achievement (Elliot, 1999). The social-emotional component of growing and developing cannot be ignored as it is a feature in one of Kenya's educational goals (Republic of Kenya, 2017). Republic of Kenya (2017) spells out that socialemotional development includes students' experiences, expressions, and management of emotions and the ability to establish positive and rewarding relationships with others. Thus, extracurricular activities entice students to be the kind of people they should be and become as each one of them is about social skills of team spirit, cooperation, competitiveness, listening and awareness of others. Elliots (1999) conducted a study at Kinsington Avenue Elementary School in Springfield, Massachusetts and found that socialemotional learning reduced behaviour problems and enhanced students' academic achievement. Also, a review of 180 school programmes in classroombased programming conducted by CASEL (Collaborative for Academic, Social and Emotional Learning) in the United States found out that students in social-emotional learning programmes demonstrated improvement in multiple areas of their personal, social and academic lives (Durlak et al., 2008).

The $17 \%(\mathrm{n}=8)$ student teachers who gave the reason for keeping students busy to control their discipline had a mean score of $72 \%$ in their teaching practice performance. One student teacher expressed that the adolescent stage is full of energy which should be exploited because left alone, they would get engaged in other antisocial activities. Moreover, co-curricular activities offered after school hours can be an excellent opportunity to discover new meaning in life rather than waste time lazing around or maybe even causing trouble out of boredom. The accomplishments displayed students' success stories which gave them an identity of being important and successful and thus raising their self-images (Woolfolk, 2013; Eggen \& Kauchak, 1999). Mbiti (1997) and Okumbe (1998) posit that students' discipline is about engaging them in collaborative activities to keep them busy. Korma (2007) explained that discipline could be achieved in schools by involving students in the decision-making of what they enjoy doing. This leads to their being responsible and accountable as they own up their choices.

\section{Head Teacher's Support and Student's Performance}

Table 3 shows head teacher's support and student teachers' performance. 
East African Journal of Education Studies, Volume 3, Issue 1, 2021

Article DOI: https://doi.org/10.37284/eajes.3.1.338

Table 3: Head teachers' support to the student teachers

\begin{tabular}{lllll}
\hline Level of support & F & \% & Mean score & Range \\
\hline Excellent & 25 & 53 & 73 & $60-80$ \\
Good & 22 & 47 & 71 & $53-80$ \\
Total & $\mathbf{4 7}$ & $\mathbf{1 0 0}$ & & \\
\hline
\end{tabular}

Table 3 shows that all the 47 students received sufficient support from the schools' administration. The $53 \%(\mathrm{n}=25)$ of the students with a mean score of $73 \%$ expressed that they received maximum support were those who managed to lift the name of their school in other schools at zonal, county and national levels. These student teachers who received excellent support were provided with accommodation in the school to appreciate and motivate them. The success in these activities raised up their self-motivation important for their academic performance (Myers, 1995; Lefton, 1991). Research has shown that positive remarks and actions by significant others in a school structure contribute towards good performance
(L'Abate, 1994). In one school, the local member of parliament and parents were invited to witness what two student teachers had done with their students in a play 'Love,' which had taken the school to the national level, attaining position four. The two students received praises and a cash reward. These two student teachers in their teaching practice scored $75 \%$ and $76 \%$, excellent results.

\section{Student Teachers' Self-Esteem Extracurricular Activities and their Performance}

Table 4 shows students' level of self-esteem sanctioned by these extracurricular activities and their final teaching practice performance.

Table 4: Student teachers' level of self-esteem at the end of teaching practice and performance

\begin{tabular}{lllll}
\hline Expressed self-esteem & f & \% & Mean score & Range \\
\hline Very high & 25 & 53 & 73 & $60-80$ \\
high & 22 & 32 & 73 & $53-80$ \\
Total & $\mathbf{4 7}$ & $\mathbf{1 0 0}$ & & \\
\hline
\end{tabular}

The results in Table 4 display that all the 47 student teachers had high self-esteem as they finished their teaching practice. The student's level of self-esteem was measured in terms of how they felt at the end of the teaching practice in relation to extracurricular activities. Self-esteem is concerned with the worth they attached to their being (Engler, 1999). Highlevel self-esteem tends to result from self-image and, therefore very confidence, while low-level selfesteem produces a low self-image and thus lacking confidence (Steffenhagen \& Burns, 1987). The 53\% $(n=25)$ with extremely high self-esteem wished they would remain in the school and continue rendering their services. In fact, some of these 25 highly motivated student teachers were given some teaching to do during the school holidays and were promised to teach positions at completion. The schools went further to celebrate them because of their good performance in the school. What emerged from the 47 student teachers was that they were all confident achievers in that they claimed that they were now teachers ready to be engaged as professional teachers.

\section{CONCLUSIONS AND RECOMMENDATIONS}

The results tend to suggest that teaching practice student teachers have an opportunity to excel through extracurricular activities, the hidden curriculum and the academic curriculum. The teaching practice school became a key place to allow a student to be and become when he or she accepted the opportunity the school offered. Certainly, the student teachers were undergoing two tests. The first one was by the school and those who could be ably rewarded. The second was through the university's supervisors who had to grade their academic performance. As the student teachers waited for the final grade in their teaching practice performance, the extracurricular curriculum ushered immediate intrinsic and extrinsic motivation, which inspired them to excel in their 
academic curriculum. It can further be argued that though teaching practice is hectic, each individual student-teacher displayed his/her professionalism in both the academic curriculum and extracurricular activities, both key dimensions of quality training.

Due to the methodology used in this research, the findings cannot be generalised across the entire population. The findings, however, provide some insight into the relationship between the participation of student teachers in extracurricular activities and their academic performance as they undertake their teaching practice. Based on this research undertaking, we recommend that institutions charged with the training of teachers consider investing in not only the academic curriculum but also in the extracurricular activities to ensure that the student-teacher is ready for a holistic educational experience. Further research may be carried out on supervisors of student teachers to establish their perceptions of engaging student teachers in extracurricular activities.

\section{REFERENCES}

Acquah, B. Y., \& Anti Partey, P. (2014). The influence of co-curricular activities on students' performance in economics. Journal of Educational Management, 6, 147-160.

Anderson, J. G. (1990). Fundamentals of educational research. London: Palmer

Bogdan, R. C., \& Biklen, S. K. (1992). Qualitative research for education. An introduction to theory and methods (2nd ed.). London: Allyn and Bacon.

Broh, B. A. (2002). Linking extracurricular programming to academic achievement: Who benefits and why? Sociology of education, 6995.

Claessen, T., Gitau, N., \& Groenewegen, T. (1995). Teaching practice handbook. A text for student teachers and university supervisors. Nairobi: Kenyatta University.

Coulangeon, P. (2018). The impact of participation in extracurricular activities on school achievement of French middle school students:
Human capital and cultural capital revisited. Social Forces, 97(1), 55-90.

Digolo, P. O. O \& Okanga, J. N (1991). Teaching practice: Theoretical basis, models and issues. In Proceedings of University of Nairobi Staff Development Workshop held at Diani Beach Hotel, Mombasa 4th to 12th August 1991.

Digolo, P. O. O. (2002). Visions on teacher education in Kenya; The teaching practice perspective. The Fountain, Journal of the Faculty of Education, 1, 90-102.

Durlak, J. A., Weissberg, R. P., Dymnicki, A. B., Taylor, R. D., \& Schellinger, K. B. (2011). The impact of enhancing students' social and emotional learning: A meta-analysis of schoolbased universal interventions. Child Development, 82(1), 405-432.

Eggen, P. D., \& Kauchak, D. (1999). Educational psychology (Vol. 403). Prentice-Hall.

Elliot, S. (1999). A multi-year evaluation of the responsive classroom approach: Its effectiveness and acceptability in promoting academic and social competence. Wisconsin: University of Madison, Madison, Wisconsin.

Engler, B. (1999). Personality Theories: An Introduction. Boston: Houghton.

Erlich, D. R., \& Shaughnessy, A. F. (2014). Student-teacher education programme (STEP) by step: Transforming medical students into competent, confident teachers. Medical teacher, 36(4), 322-332.

Eshiwani, G. E. (1993). Education in Kenya since independence. Nairobi: East African Educational Publishers.

Fraenkel, J. R., Wallen, N. E., \& Hyun, H. H. (1993). How to design and evaluate research in education (Vol. 7). New York: McGraw-hill.

Gardner, H. (1999). Intelligence reframed. New York: Basic Books.

Gathua, S. M. (1990). Instructional Problems Constraining the Teaching of Physical Education in Kenya Special Primary Schools for

114| This work is licensed under a Creative Commons Attribution 4.0 International License. 
the Physically Handicapped. Unpublished Thesis. Nairobi: Kenyatta University.

Heeralal, P. J. H. (2014). Mentoring needs of preservice teachers during teaching practice. A case study at a South African university. Journal of Educational and Social Research,4(1), 511511.

Igaga, J. M. (1972). A guide to teaching practice in Africa. Nairobi: Oxford University Press.

Jenkinson, A. K. \& Benson, C. A. (2010). Barriers to providing education and physical activity in Victorian state secondary schools. Australian Journal of Teacher Education, 36 (1), 1-17

Kasomo, D. (2012). An evaluation of teaching in Kenya. Education, 2(4), 66-72.

Korma, J. W. (2007). An investigation on factors contributing to students' strikes in public schools. Unpublished research project on education. University of Nairobi

L'Abate, L. (1994.) A Theory of Personality. New York: John Willey and Sons.

Lefton, L. A. (1991). Psychology (4th ed.). Singapore: Allyn and Bacon.

Macan, T. H., Shahani, C., Dipboye, R. L., \& Phillips, A. P. (1990). College students' time management: Correlations with academic performance and stress. Journal of educational psychology, 82(4), 760. - 768

Marsh, H., \& Kleitman, S. (2002). Extracurricular school activities: The good, the bad, and the nonlinear. Harvard educational review, 72(4), 464-515.

Mbiti, D. M. (1997). Foundations of school administration. London: Oxford University Press.

McLeod, J. (1999). Practitioner Research in Counselling. London: Sage.

Msangya, B. W., Mkoma, S. L., \& Yihuan, W. (2016). Teaching practice experience for undergraduate student teachers: A case study of the Department of Education at Sokoine
University of Agriculture, Tanzania. Journal of Education and Practice, 7(14), 113-119.

Mungure, D. M. (2016). An Exploration of the Preparation and Organization of Teaching Practice Exercise to Prospective Science and Mathematics Teachers toward Improving Teaching Profession at Morogoro Teachers' College. Journal of Education and Practice, 7(33), 212-220.

Myers, D. G. (1995). Psychology (4th ed.) New York: Worth

Okumbe, J. A. (1998). Education Management Theory and Practice. Nairobi: University of Nairobi Press.

Omoke J. P. (2009). The role of cocurricular activities in social and academic development of students in Suneka, Division of Kisii South District. Unpublished research project, The Catholic University of Eastern Africa.

Republic of Kenya. (2017). Basic Education Curriculum Framework. Nairobi: Kenya Institute of Curriculum Development.

Shiundu, J. S. \& Omulando, S. J. (1992). Curriculum: Theory and practice in Kenya. Nairobi: Oxford University Press.

Steffenhagen, R. A. \& Burns J. D. (1987). The Social Dynamics of Self-esteem: Theory of Therapy. New York: Praeger

Tabot, B. (2015). Contextual Characteristics of Teaching Practice Schools and Supervision of Student Teachers in Kenya. Journal of Educational Policy and Entrepreneurial Research, 2, 2408-770.

Woolfolk, A. (2013). Educational Psychology. New Jersey: Pearson.

World Health Organization. (2010). Global recommendation physical activity for health. Geneva: WHO.

115 This work is licensed under a Creative Commons Attribution 4.0 International License. 